\title{
Ratio Analysis used to compare the performance of Tata steel and Jindal Steel. (A comparative study)
}

\author{
*Manish Roy Tirkey \& ** Mustafa Osamah \\ *Asst. professor **M.Com Financial Accountacy Student \\ *Sam Higginbottom institute of agriculture Technology and Sciences, Allahabad \\ **University of Misan, Misan IRAQ
}

\begin{abstract}
This study is conducted purely based on secondary data obtained through website of the specified private banks. By using the ratio analysis tool we can analyse the performance of both the steel industry of India and we can easily find out the strength and weakness of the companies and their position in the market. Different ratios are used in this study and particularly those which are related to the financial statement for this purpose balance sheet of 2009-2012 of both the banks are used and from them ratios are calculated so according to which we can easily compare the banks performance and tell which private banks grow faster and whose position is better than the other one. After comparing the financial position it is clear that position of Tata steels is much better than the Jindal steels.
\end{abstract}

Keywords: Balance sheet, Companies, Ratio analysis, Steel Companies.

\section{Introduction}

Ratio analysis is such a significant technique for financial analysis. It indicates relation of two mathematical expressions and the relationship between two or more things. Financial ratio is a ratio of selected values on an enterprise's financial statement.

There are many standard ratios used to evaluate the overall financial condition of a corporation or other organization. Financial ratios are used by managers within a firm, by current and potential stockholders of a firm, and by a firm's creditor. Financial analysts use financial ratios to compare the strengths and weaknesses in various companies.

\section{Essence of ratio analysis:}

Financial ratio analysis helps us to understand how profitable a business is, if it has enough money to pay debts and we can even tell whether its shareholders could be happy or not.

Financial ratios allow for comparisons:

1. between companies

2. between industries

3. between different time periods for one company

4. between a single company and its industry average

To evaluate the performance of one firm, its current ratios will be compared with its past ratios. When financial ratios over a period of time are compared, it is called time series or trend analysis. It gives an indication of changes and reflects whether the firm's financial performance has improved or deteriorated or remained the same over that period of time. It is not the simply changes that has to be determined, but more importantly it must be recognized that why those ratios have changed. Because those changes might be result of changes in the accounting polices without material change in the firm's performances.

Another method is to compare ratios of one firm with another firm in the same industry at the same point in time. This comparison is known as the cross sectional analysis. It might be more useful to select some competitors which have similar operations and compare their ratios with the firm's. This comparison shows the relative financial position and performance of the firm. Since it is so easy to find the financial statements of similar firms through publications or Medias this type of analysis can be performed so easily.

To determine the financial condition and performance of a firm, its ratios may be compared with average ratios of the industry to which the firm belongs. This method is known as the industry analysis that helps to ascertain the financial standing and capability of the firm in the industry to which it belongs.

Industry ratios are important standards in view of the fact that each industry has its own characteristics, which influence the financial and operating relationships. But there are certain practical difficulties for this method. First finding average ratios for the industries is such a headache and difficult. Second, industries include companies of weak and strong so the averages include them also. Sometimes spread may be so wide that the average may be little utility. Third, the average may be meaningless and the comparison not possible if the firms with in the same industry widely differ in their accounting policies and practices. However if it can be 
standardized and extremely strong and extremely weak firms be eliminated then the industry ratios will be very useful.

\section{Objectives of the study}

1. To study the financial performance of Tata steel and Jindal steel.

2. To compare the financial performance of Tata steel and Jindal steel.

\section{Research Methodology}

In this present study, an attempt has been made to evaluate and compare the financial performance of Tata steel and Jindal steel and both of the companies are related with the private sector. The study is based on secondary data and the details are collected through websites, magazines and journals. The time period of study is four years 2009 to 2012. Ratio analysis was applied to analyse the performance of these companies.

\section{Following Ratios are used for this Study.}

1. Current Ratio.

2. Debt equity ratio.

3. Inventory turnover ratio.

4. Fixed asset turnover ratio.

5. Net operating profit per share.

6. Return on capital employed.

7. Dividend payout ratio.

8. Earnings per share.

\section{DATA ANLYSIS}

1. Current ratio

\begin{tabular}{|l|l|l|l|l|}
\hline Particulars & 2009 & 2010 & 2011 & 2012 \\
\hline Tata steels & .91 & 1.12 & 1.78 & .79 \\
\hline Jindal steels & 1.04 & .65 & .79 & .69 \\
\hline
\end{tabular}

Source : Dion Global Solutions Limited

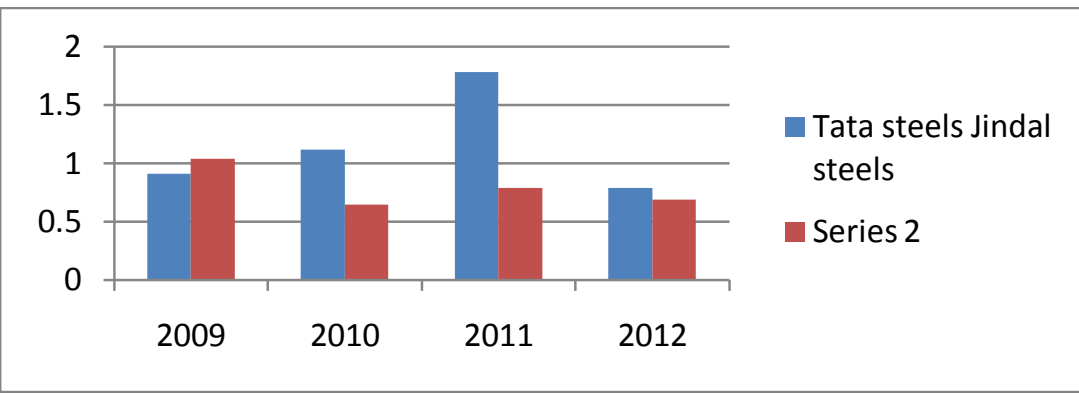

From the above graph and table it is clear that Current ratio of Tata steel increasing from 2009 to 2011 but fall down in 2012 and it is highest in the year 2011 on the other hand the current ratio of Jindal steels fluctuating from 2009 to 2012. It indicates the company's ability to meet the short term debts.

2. Debt Equity ratio.

\begin{tabular}{|l|l|l|l|l|}
\hline Particulars & 2009 & 2010 & 2011 & 2012 \\
\hline Tata steels & 1.34 & .68 & .59 & .45 \\
\hline Jindal steels & .92 & 1.24 & 1.39 & 1.33 \\
\hline
\end{tabular}

Source: Dion Global Solutions Limited

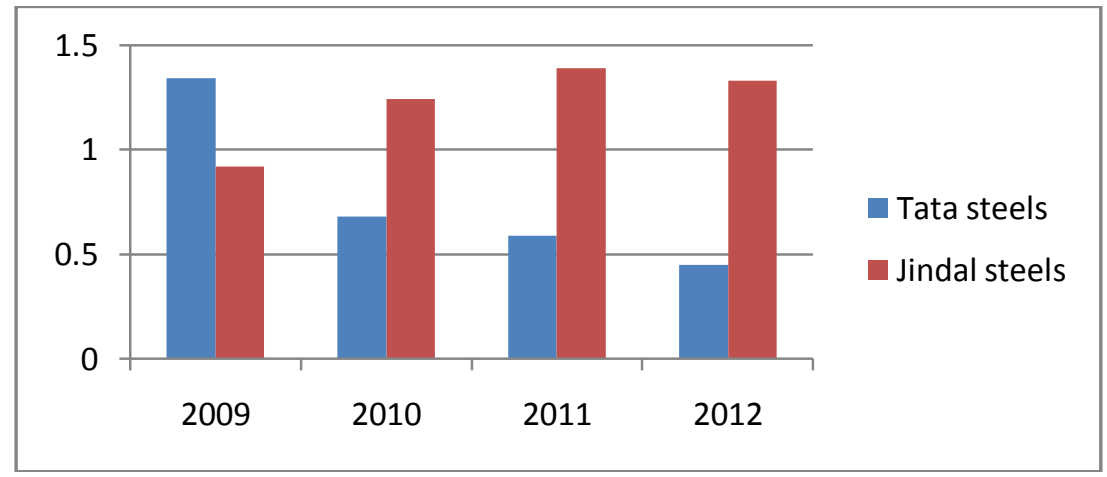


From the above table it is clear that the debt equity ratio of Tata steels goes downward from 2009 to 2012 while the Jindal steels debt equity ratio increase in two year and then slightly reduced in 2012. Debt-to-equity ratio $(\mathrm{D} / \mathrm{E})$ indicating the relative proportion of shareholders' equity and debt used to finance a company's assets.

3. Inventory Turnover ratio.

\begin{tabular}{|l|l|l|l|l|}
\hline Particulars & 2009 & 2010 & 2011 & 2012 \\
\hline Tata steels & 9.36 & 10.90 & 9.85 & 9.40 \\
\hline Jindal steels & 9.08 & 8.05 & 5.81 & 4.83 \\
\hline
\end{tabular}

Source: Dion Global Solutions Limited

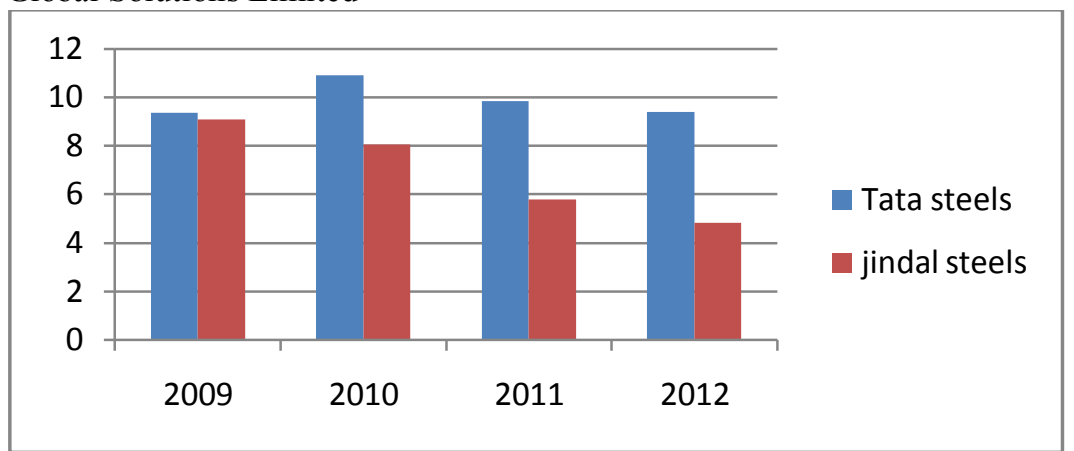

From the above graph and table it is clear that Inventory turnover ratio of Tata steels is high in comparison to Jindal steels it shows the company's efficiency in turning its inventory into sales. A low turnover rate indicates poor liquidity. Here Jindal steel performance is not good in comparison to Tata steels.

4. Fixed asset turnover ratio.

\begin{tabular}{|l|l|l|l|l|}
\hline Particulars & 2009 & 2010 & 2011 & 2012 \\
\hline Tata steels & 1.22 & 1.12 & 1.29 & 1.48 \\
\hline Jindal steels & 1.04 & .83 & .75 & .88 \\
\hline
\end{tabular}

Source: Dion Global Solutions Limited

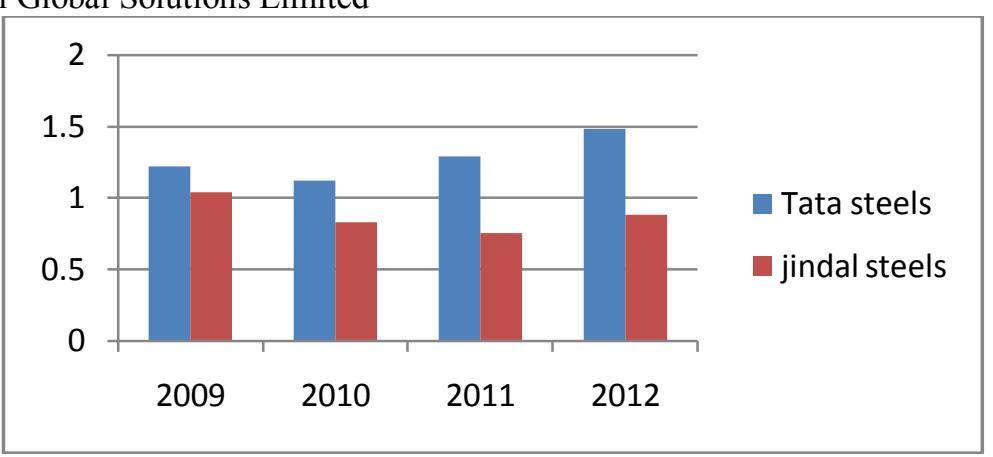

From the above table and graph it is clear that the ratio of Tata steels were high in the year 2009, 2011 and 2012. Jindal steels ratio was high in the year 2009 and 2012.it shows that Tata steels has been more effective in using the investment in fixed assets to generate revenues.

5. Net operating profit per share.

\begin{tabular}{|l|l|l|l|l|}
\hline Particulars & 2009 & 2010 & 2011 & 2012 \\
\hline Tata steels & 333.27 & 281.11 & 305.53 & 348.41 \\
\hline Jindal steels & 496.46 & 78.90 & 102.15 & 142.13 \\
\hline
\end{tabular}

Source: Dion Global Solutions Limited

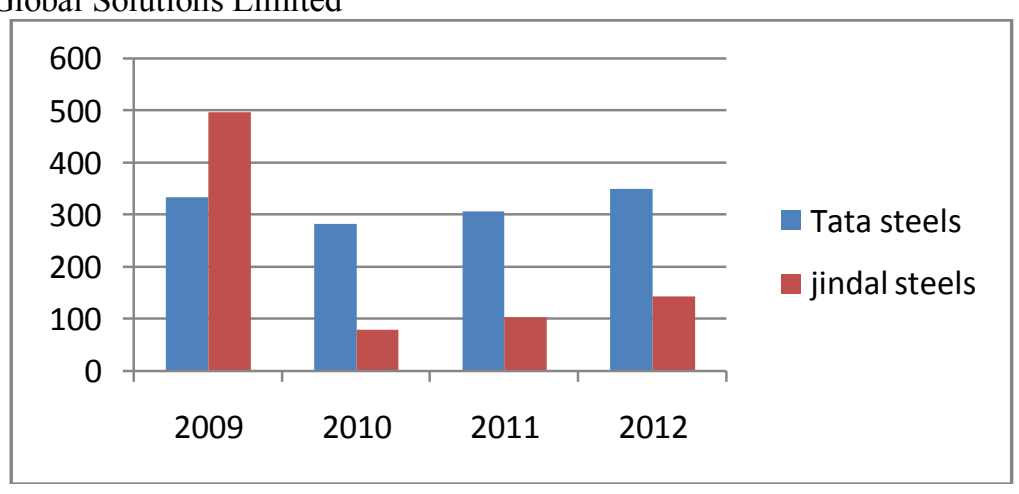


From the above table and graph it is clear that net operating profit per share of Tata steels is consistently good in 2009-2012 while Jindal steels net operating profit was high in 2009.

6. Return on capital employed

\begin{tabular}{|l|l|l|l|l|}
\hline Particulars & 2009 & 2010 & 2011 & 2012 \\
\hline Tata steels & 15.01 & 13.06 & 13.48 & 15.03 \\
\hline Jindal steels & 23.16 & 14.86 & 15.67 & 13.40 \\
\hline
\end{tabular}

Source: Dion Global Solutions Limited

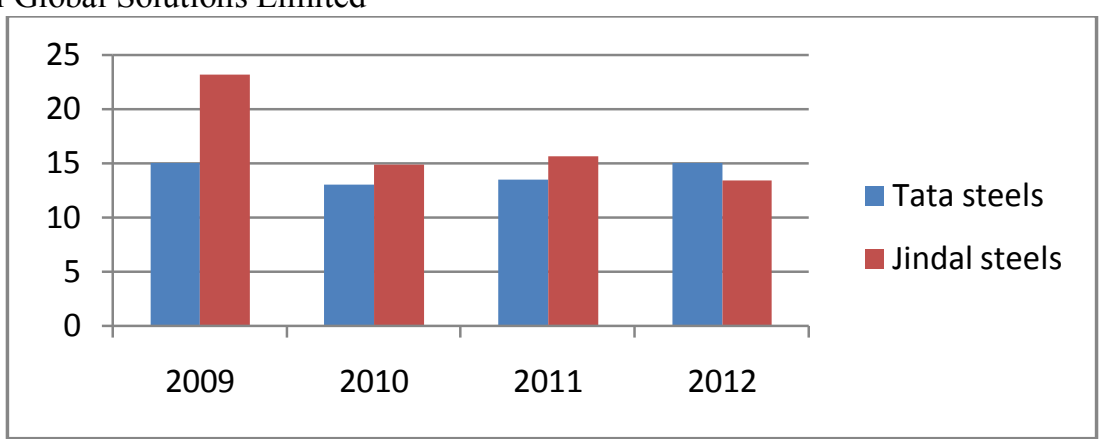

From the above table and graph we are able to tell that which companies return on investment is better in 2009 Jindal steels return on capital is better in 2010 it goes down while in Tata steels return on capital employed fluctuates in these four years it were high in 2009 and 2012 while low in 2010 and 2011.

7. Dividend payout ratio net profit.

\begin{tabular}{|l|l|l|l|l|}
\hline Particulars & 2009 & 2010 & 2011 & 2012 \\
\hline Tata steels & 27.15 & 16.64 & 19.04 & 20.11 \\
\hline Jindal steels & 5.55 & 8.16 & 6.97 & 7.23 \\
\hline
\end{tabular}

Source: Dion Global Solutions Limited

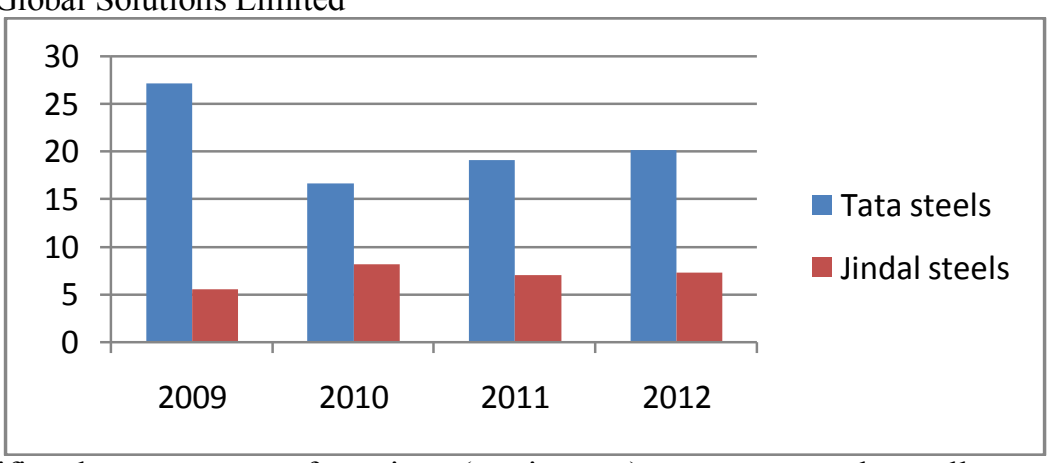

This ratio identifies the percentage of earnings (net income) per common share allocated to paying cash dividends to shareholders. From the above table it is clear that Dividend payout ratio of Tata steels were high in all the years in comparison to Jindal steels which has low dividend payout ratio.

8. Earnings per share.

\begin{tabular}{|l|l|l|l|l|}
\hline Particulars & 2009 & 2010 & 2011 & 2012 \\
\hline Tata steels & 69.70 & 56.37 & 71.58 & 68.95 \\
\hline Jindal steels & 99.35 & 15.89 & 22.09 & 22.58 \\
\hline
\end{tabular}

Source: Dion Global Solutions Limited

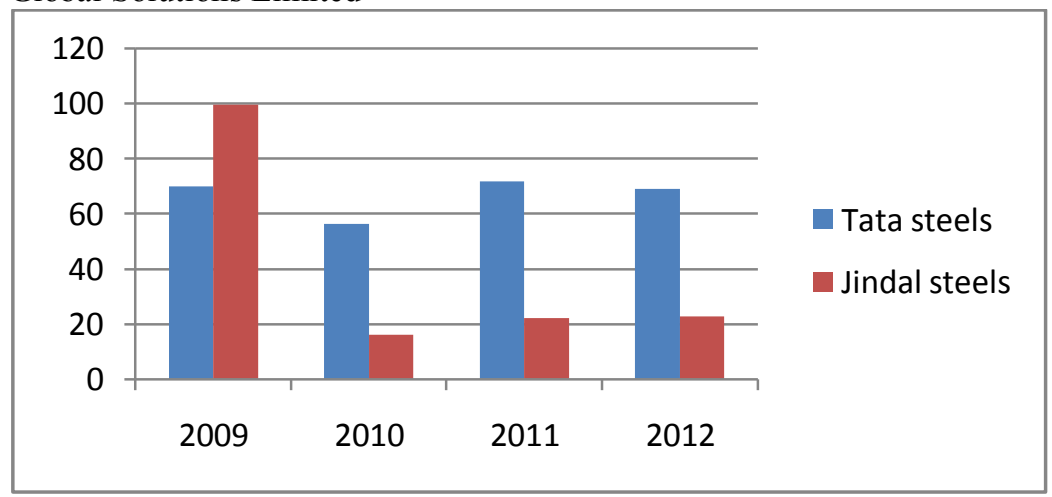


From the above table and graph it is clear that earnings per share of Tata steels were better in all these years 2009-2012. While in Jindal steels it performance was good in 2009 but in 2010,2011 and 2012 it goes down.

\section{Conclusion}

After analysing the above ratio it is clear that the position of Tata steels is better in comparison to Jindal steels. In above 8 ratio which we see through graph and table it is shown that in 6 ratio Tata steel company is performing better while the position of Jindal steels is good but in comparison to Tata steels position was not good.

\section{References}

[1]. Alexander, D., Britton, A., Jorissen, A. (2007) International Financial Reporting and Analysis, 3rd edition. London: Thomson Learning.

[2]. European Commission (2008) Final Report of the Expert Group Accounting Systems for Small Enterprises - Recommendations and Good Practices. European Commission Enterprise and Industry Directorate-General.

[3]. Eurostat (2011) Key figures on European business with a special feature on SMEs. Dostuno na: http://epp.eurostat.ec.europa.eu/cache/ITY OFFPUB/KS-ET-11- 001/EN/KSET-11-001-EN.PDF (10-01-2012)

[4]. FINA (2011) Poslovanje malog poduzetništva u 2009. i 2010. godini. Zagreb: Financijska agencija.

[5]. Gibson, C. H. (2011) Financial Statement Analysis, 12th Edition. Canada: South-Western, Cengage Learning.

[6]. Halabi, A. K., Barrett, R., Dyt, R. (2010) Understanding Financial Information Used to Assess Small Firm Performance. Qualitative Research in Accounting \& Management, 7 (2), pp 163-179

[7]. HGK (2010) Malo gospodarstvo. Hrvatska gospodarska komora; Sektor za industriju. na:http://www2.hgk.hr/en/depts/industry/Malo_gospodarstvo_2010.pdf(14-01-2012)

[8]. IFAC (2011) Small and medium-sized enterprises have been recognized as a separate but very important economic discipline Practice Management Tips for SMPs. IFAC: Small and Medium Practices Committee.

[9]. Osteryoung, J., Constand, R., Nast, D. (1992) Financial Ratios in Large Public and Small Private Firms. Journal of Small Business Management, 30 (3), pp 35-46

[10]. Sever, S. (2007) Uloga financijskih i nefinancijskih pokazatelja u revizorovoj ocjeni kvalitete poslovanja. Magistarski rad. Zagreb: Ekonomski fakultet.

[11]. Thomas, J., Evanson, R. V. (1987) An Empirical Investigation of Association Between Financial Ratio Use and Small Business Success. Journal of Business Finance \& Accounting, 14(4), pp 555-571

[12]. VSBDC (2004) Financial Statement Analysis for Small Businesses; A Resource Guide. Virginia Small Business Development Center Network.

[13]. www.moneycontrol.com 